\title{
The Interrelations of Stomatal Aperture, Leaf Water-content, and Transpiration Rate.
}

\author{
BY
}

\author{
R. C. KNIGHT, \\ From the Department of Plant Physiology and Pathology, Imperial College of Science and \\ Technology, London.
}

With four Figures in the Text.

RECENT investigators of transpiration have directed their attention R towards the relative importance of the various factors controlling the rate of water loss from a plant. It was formerly held that the function of the regulation of transpiration was efficiently discharged by the stomata, and that, therefore, changes of stomatal aperture and of transpiration rate ran closely parallel; on this assumption Darwin based his horn hygroscope and differential temperature methods of estimating stomatal aperture $(7,8)$.

Lloyd (1908) was the first to call in question the completeness of stomatal control of transpiration (19); he even went so far as to conclude, from the lack of coincidence of the graphs of transpiration and stomatal aperture, that stomatal regulation of transpiration did not occur except when the stomata were almost, or completely, closed.

Darwin in I9I6 (9) concluded that the differences between the graphs of transpiration rate and of stomatal aperture were not sufficiently important to justify the exclusion of stomata as the factor regulating transpiration.

Livingston (17) in 1906 attacked the problem in a different manner. He attempted to eliminate the influence of atmospheric conditions by expressing his results in terms of 'relative transpiration'. He found that the transpiration rate rose during the early morning hours, but the rise was checked before the evaporating power of the air, as measured by the rate of water loss from an atmometer, reached a maximum. In other words, some factor other than external atmospheric changes (which regulate, of course, the water loss of the atmometer) tends to reduce the rate of transpiration after a certain time.

The existence of this inhibiting factor has been demonstrated in various plants by Shreve (21) and Giddings (12) in a similar manner, and also by

[Annals of Botany, Vol. XXXI. No. CXXII. April, 1917.] 
Bakke (1), Trelease and Livingston (22), and Bakke and Livingston (2), using the hygrometric paper method. In addition to this 'early maximum' of transpiring power, a secondary maximum has also been found by Bakke (1), Shreve (21), and by Bakke and Livingston (2) in various plants.

The regulating mechanism concerned in this retardation was not, in Livingston's opinion, stomatal in nature because of its early appearance before any stomatal closure was to be expected. Trelease and Livingston have since demonstrated the correctness of this view by actual porometer experiments, which showed that the maximum stomatal aperture was reached some three hours later than the maximum of transpiring power.

A suggested explanation of the checking of the transpiration rate was forthcoming as the result of an investigation by Livingston and Brown in 1912 (18). They found that the water-content of transpiring leaves was not constant throughout the day, but that it tended to decrease during the morning hours and reached a minimum at about the same time as the evaporating power of the air reached a maximum, i.e. some time after the maximum of transpiring power. The suggestion offered was that as the evaporating power of the air increases a corresponding increase in transpiration results, which reduces the water-content of the leaf. The decrease in water-content, in turn, tends to lower the transpiration rate, by the 'incipient drying' of the walls of the transpiring cells, in a manner similar to that in which a Piche paper atmometer tends to dry out as the result of excessive evaporation.

Shreve (21) has confirmed the work of Livingston and Brown and agrees with their interpretation of the experiments.

Briggs and Shantz (5) in I9I6 concluded, as the result of an extensive series of experiments upon the influence of environmental factor on transpiration, that the transpiration coefficient of the plants investigated changes during the day, and they ascribed the change to stomatal control or to lack of water.

Iljin (13) found that the osmotic pressure of the guard cells was much greater than that of the other epidermal cells when the stomata were open, but when the stomata were closed the osmotic pressures of all the epidermal cells were the same. He also found that the graphs of transpiration rate and of the osmotic pressure of the guard cells were parallel, and suggested that excessive transpiration reduced the osmotic pressure of the guard cells thus producing stomatal closure and inhibition of transpiration. He found, however, that the rate at which the stomata closed was not dependent upon the rate of removal of water from the plant. Also he frequently found open stomata in wilted plants.

It may be observed here that two investigators quoted by Lloyd (19, pp. 60, 6I) have made observations which supply evidence supporting the theory of the action of incipient drying. Unger (1862) and Comeo 
(1878) both found that when transpiration from one surface of a leaf is stopped, the transpiration rate of the other surface is greatly increased.

A possible explanation is that by decreasing the transpiration rate of a portion of the leaf, the water-content was increased and therefore the transpiration rate of the rest of the leaf was increased.

The present investigation is concerned primarily with the relation of stomatal size to transpiration rate. It was undertaken at the suggestion of Professor V. H. Blackman, and I desire to express my gratitude to him for helpful advice and criticism.

\section{METHODS.}

For the experiments on stomatal aperture the porometer method (Darwin and Pertz, 11) was used and a preliminary investigation was carried out to determine the precautions necessary when using the method. The results of this have already been reported (Knight, 15). In some of the following experiments the self-recording apparatus previously described (Laidlaw and Knight, 16) has been used; in others the method of timing bubbles with a stop-watch (Knight, 14). The usual practice was to attach three leaf chambers to leaves of different ages and to connect all three to the same recording apparatus, thus obtaining an average reading (see Balls, 3, and Knight, 15, p. 75). Sometimes two chambers were employed, and occasionally only one.

Darwin has pointed out $\left(9, \mathrm{p} . \mathrm{4}^{\mathrm{I}} 5\right)$ that transpiration through stomata is most likely to be proportional to the square root of the rate of flow of the air through the porometer, and accordingly he uses the square root of the porometer readings to represent the aperture of the stomata. The same course has been followed in the present work.

The measurements of transpiration were made throughout by means of periodical weighings, the periods generally being of 30 minutes duration.

Concurrently with the records of transpiration rates the evaporating power of the air has also been determined by weighings of an atmometer. Several forms of this instrument have been used, including the Livingston standard earthenware type and a modification of the Piche paper form. The latter was found to respond more quickly to temperature changes than the earthenware types.

By comparing the transpiration and evaporation rates it was possible to obtain figures which were proportional to relative transpiration; but the figures given in the following tables do not actually represent relative transpiration because the rates of transpiration and evaporation were not calculated for unit areas, and also because different atmometers were used in different experiments. For the same reasons the transpiration and evaporation ratios of different experiments are not comparable.

The importance of controlling the conditions of air movement during 
transpiration experiments has already been pointed out, and throughout the present work the 'air-flue' elsewhere described (Blackman and Knight, 4) has been employed to produce air-currents of constant velocity. The plants and atmometers under observation were placed close together in the glass section of the flue. At first, weighings were made on a balance standing on the roof of the flue above the plants, the latter being suspended from the balance beam by a wire hook. The fan drawing air through the flue was stopped for a period sufficient to carry out the weighings. It was found more convenient, when more than two plants or atmometers were under observation, to remove each from the flue in order to weigh it, rather than stop the fan for so long a period. When porometer cups were attached to plants to be weighed, it was necessary, of course, to interrupt the record and to disconnect the recording apparatus during weighing.

Various plants were used for the experiments, including Fuchsia (garden hybrid), Antirrhinum, Helianthus annus, H. tuberosus, Catalpa Kaempferi, Ricinus communis, Pelargonium zonale (variety), Eupatorium adenophorum, E. Raffilli, Choisya ternata, Aucuba japonica (small and large-leaved forms), and Veronica speciosa (variety). Of these, the most useful was found to be Eupatorium adenophorum. This plant is easily propagated from cuttings and can be kept healthy throughout the winter in a cool greenhouse. It is suitable for transpiration experiments, because its rate of water loss is sufficiently high to be easily measurable, and is convenient for porometer experiments, owing to the ease with which the leaf chamber can be fixed to the leaf, which is neither hairy nor unduly smooth. The stomata are confined to the under surface of the leaves and are rather small, but are quite active in their response to changes of illumination.

My thanks are due to Mr. W. Hales, Curator of Chelsea Physic Garden, who has, throughout this work, maintained for me an ample stock of the necessary plant material.

Experiments have been carried out, using potted plants and also cut shoots mounted in a potometer. In the former case the pot was enclosed in the usual aluminium sheath and the top covered with rubber sheeting. The whole was placed on a small retort stand and the cups for the potometer were held in clamps. The retort stand was weighed with the plant on a large balance.

In the experiments with cut shoots, the potometer was made from a small burette or graduated pipette which was sealed to one arm of a Ushaped tube. The other arm of this was attached to the cut stem of the plant by a short piece of rubber pressure-tubing, which kept the shoot upright. The curved portion of the U-tube was fastened to a wooden stand, to obviate the need of clamping in an upright position. Porometer cups were held in holes in flat pieces of wood (garden labels answer the purpose well), which were wired to screw-clips gripping the burette or 
pipette. These improvised clamps sometimes interfered with the readings of the potometer, but were very convenient to adjust and were relatively light.

Transpiration rates were determined by weighings; readings of the potometer were made simultaneously in order to indicate the amount of water absorbed by the shoot and consequently any changes in the watercontent of the plant.

\section{Experiments on the Potometer Method.}

Curtis (6) and Livingston (17) have taken exception to methods which involve mutilation of the plant, such as detaching a shoot and using it in a potometer, since such treatment is liable to cause the plant to behave in an irregular manner. Lloyd $(19,20)$ appears to have found the potometer satisfactory, and as the method is convenient some experiments were carried out to compare the behaviour of plants in pots with that of cut shoots set up in a potometer.

Leaf chambers were fixed to three leaves of each of two shoots on a plant of Eupatorium adenophorum and porometer readings taken simultaneously from each shoot by means of the automatic recorders. After a few hours one shoot was severed from the plant, a fresh surface was cut, under water, four inches above the first cut, to exclude the air as far as possible from the water-conducting system, and the cut shoot was mounted in a potometer, the porometer records being continued for some hours with the shoot in the potometer. The graphs of stomatal aperture ran closely parallel until one shoot was severed from the plant; but when this was done the stomata of the severed shoot immediately began to close, the movement lasting about ten minutes. From this point onwards they opened again until, about fifty minutes after the shoot was cut, the two graphs bore the same relation to each other as before cutting. There seems to be no doubt that the temporary tendency to close was due to the handling involved in cutting the shoot and mounting it in the potometer. Other examples of this phenomenon have been described elsewhere (Knight, 15, p. 59).

Records of the stomatal behaviour of shoots in potometers have been continued for as long as three days after setting up, and it has been found that the graphs of stomatal aperture correspond closely for the whole period with those obtained at the same time from potted plants under the same conditions. The differences are no greater than are normally to be found between different potted plants in these circumstances. In the case of the cut shoots, about half an inch of the end of the stem was cut off every day in order to provide a fresh absorbing surface.

Similar experiments have been carried out with regard to the transpira- 
tion of severed shoots in a potometer, and the following is a typical example :

A shoot was severed under water at 2.0 p.m. on October 4 th, and mounted in the usual manner in a potometer. Porometer and transpiration measurements were made up to 6.0 p.m., and continued from II.0 a.m. till 3.0 p.m. on October 5 th. During that day the stomata responded in the usual manner to the illumination changes and the rate of transpiration also was comparable with that of a rooted plant. Comparison of the potometer readings and weighings showed that the plant was not suffering from lack of water, the quantity absorbed being equal to the quantity transpired. During October 6th transpiration and stomatal movement went on as usual, but it was found at 2.0 p.m. that the rate of absorption of water was slightly below the rate of transpiration and therefore the water-content of the plant was diminishing. There was no apparent wilting, however, until an hour later, when the leaves were distinctly flaccid. At this stage an inch of the end of the stem was removed, to provide a fresh absorbing surface, and the plant immediately began to absorb at a greater rate, so that by 5.0 p.m. the leaves had almost recovered their former turgidity. By Io a.m. on October I 7 th the plant, having absorbed during the night more water than it had. transpired, was quite turgid, and the observations were continued. By noon, however, wilting had commenced again and the experiment was stopped, although, as the plant was apparently quite healthy, there appeared to be no reason why a freshly cut absorbing surface should not again have enabled it to recover.

It appeared then from these experiments that as far as transpiration and stomata are concerned, a shoot in a potometer is capable in ordinary environment of carrying on its functions normally for some two or three days after its removal from the plant. It was found, as was to be expected, that plants raised out of doors remained normally active for longer periods after mounting in the potometers than similar ones grown in a greenhouse. Since, therefore, most of the experiments in this work lasted less than twenty-four hours, it was considered legitimate to draw conclusions from the behaviour of plants mounted in potometers.

Consideration was given to the possibility that, as the plants were placed in the air-flue during the experiments, the continuous stream of air passing over the leaves might cause some change of stomatal aperture, e.g. the closure due to shaking already referred to. Although the speed of the air-current was never sufficiently high to cause any visible movements of the leaves, nevertheless experiments were carried out to test the possible effects of the wind on the stomatal aperture. Rooted plants and shoots in potometers have been placed in the flue and subjected for short and long periods to air-currents of velocities up to twenty metres per minute. Periods with the air moving have been alternated with periods of fairly still 
air, by stopping the fan and closing the ends of the flue with wooden shields. Also control plants have been kept outside the flue. It has not been possible to demonstrate any significant difference between the stomatal records of plants in still air and those subjected to a wind of velocity twenty metres per minute when other conditions are similar.

Another possible source of stimulation of the stomata is the movement of the plants when weighings are made. In the case of Eupatorium adenophorum, at least, it was sometimes found that after a weighing had been made the stomata were less widely open than immediately before the recorder was disconnected, and that a few minutes elapsed before they attained their former aperture. This slight movement was, of course, quite distinct from any normal changes due to differences of illumination, \&c., and was ascribed to shock. If care is taken in moving the plants, it is a simple matter to prevent any closure at all, and it is very likely that this response to shock is not shown by all plants. It is, however, a matter for precaution.

\section{Experiments on Stomatal Aperture and Transpiration.}

This series of some twenty-six experiments was carried out at various times of the year in a greenhouse and most of the species in the list given above were used. In some cases rooted plants were used and in others shoots mounted in potometers. In either case the plant was often made ready for the experiment overnight, in order that in the morning the experiment could be started before the occurrence of maximal values in the functions under observation.

The results, as far as they concern the inter-relationship of stomatal aperture and transpiration, were distinctly discordant. In some experiments the graphs of relative transpiration and stomatal aperture ran closely parallel, a maximum in the case of one coinciding with a maximum in the other. On the other hand, in many experiments there appeared to be no correlation whatever between the two graphs.

Below are given the results of two experiments of the series, representing extreme cases of agreement and discrepancy, respectively, between the graphs of stomatal aperture and relative transpiration.

Experiment 12. The plant used was Helianthus tuberosus, a species with large stomata on both surfaces of the leaf and a high transpiration rate. Halfhourly measurements of the evaporating power of the air and of transpiration rate were made, and the ratio of the two gives numbers proportional to 'relative transpiration'. The quantity of water absorbed by the plant during each thirty minutes was determined by potometer readings, and changes of stomatal aperture were recorded by porometer determinations every ten or fifteen minutes. Table I gives the results, which are also expressed graphically in Fig. $\mathrm{I}$. 
In the experiments given in the tables below the weighing of the plant and the reading of the potometer were in each case made one and a half minutes earlier than the weighing of the atmometer, so that the periods represented by the numbers for transpiration and absorption fell one and a half minutes earlier than those represented by the numbers for atmometer loss, although the tables and figures show the respective periods as coincident.

The numbers in the column $\frac{T}{E}$ are proportional to, not equal to, 'relative transpiration', since they are not calculated for unit areas.

The numbers in the last column, 'Stomatal aperture', are obtained from the square roots of the reciprocals of the time readings of the porometer.

\section{TABLE I.}

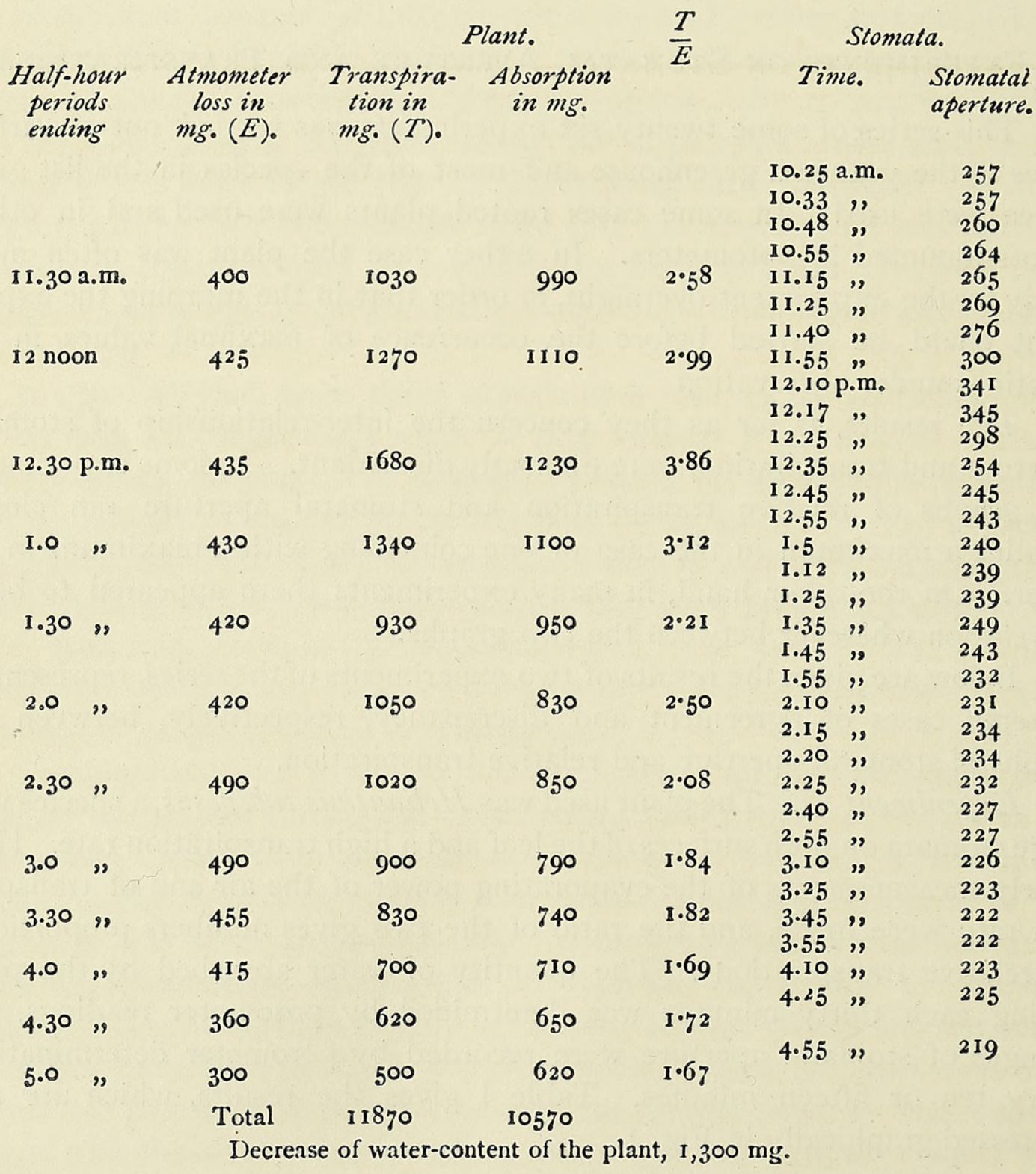




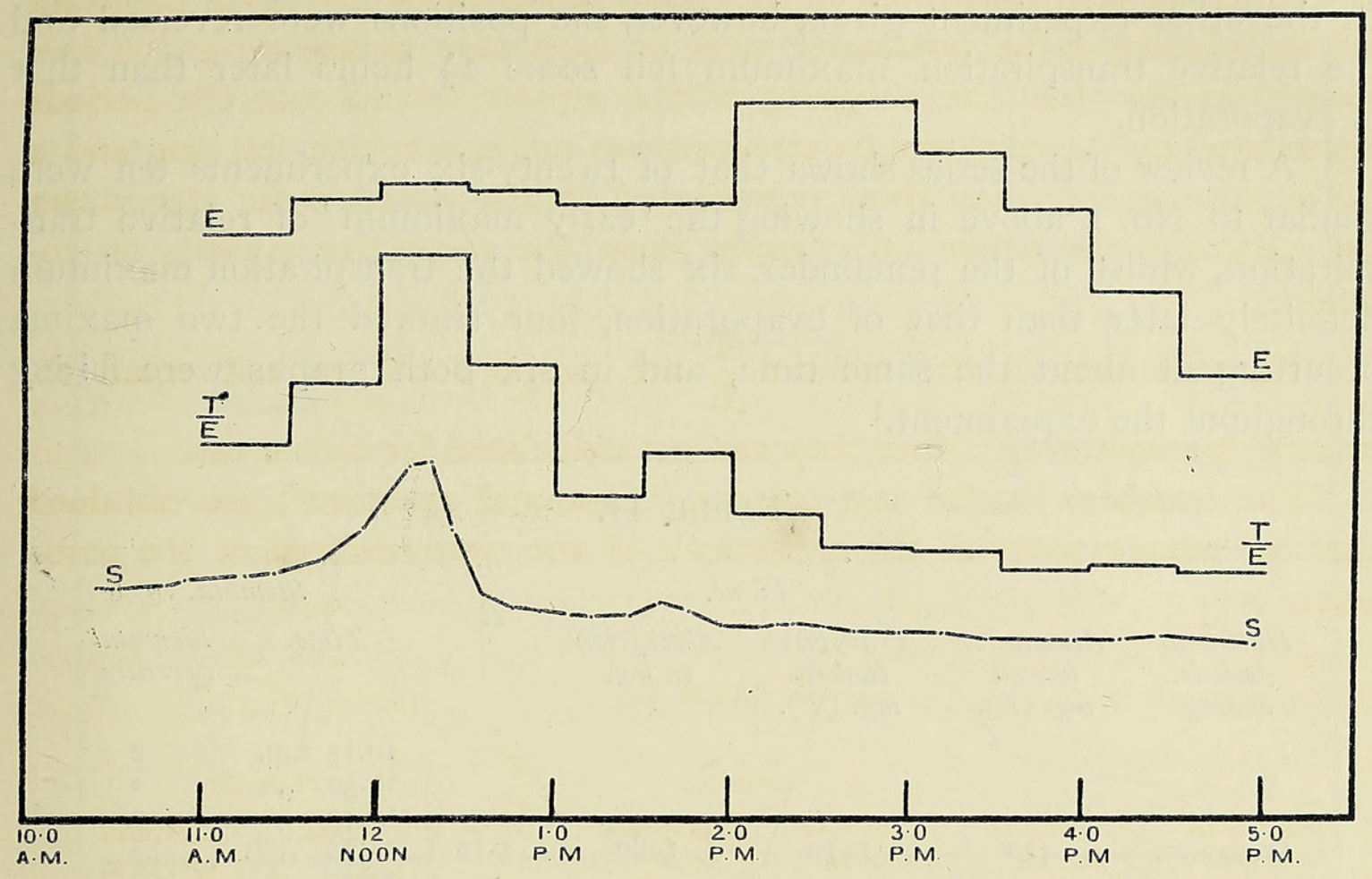

FIG. r. Graphs (based on results given in Table I) showing parallelism between stomatal aperture and relative transpiration. The graphs in this and the succeeding figure are plotted on different base lines for the sake of clearness. $S=$ stomatal aperture; $E=$ atmometer $\operatorname{loss} ; \frac{T}{E}=$ relative transpiration.

The close agreement between the two is clearly shown by the maximum occurring in each between $\mathrm{I} 2$ noon and $\mathrm{I} 2.30$ p.m., and the small secondary maximum between I.30 p.m. and 2 p.m.

Experiment II. A plant of Helianthus tuberosus was also used in this experiment, which was carried out in a manner exactly similar to that in Experiment I2. The results are shown in Table II and Fig. 2.

In this case the two graphs appear to be quite independent of each other. Stomatal aperture reached a maximum at $11.45 \mathrm{a} . \mathrm{m}$. and a second maximum at I.55 p.m., but the relative transpiration graph shows only one maximum, and that between 2.50 p.m. and 3.20 p.m.

From these experiments it is apparent that stomatal size and transpiration rate are not always in close agreement, and this result supports the conclusions reached by Lloyd using similar methods $(19, \mathrm{p} .6 \mathrm{I})$. Darwin (9), however, claims to have shown a much closer agreement between the graphs of transpiration and stomata than has been found in the present work.

In the above series of experiments, confirmation was sought of the observation of Livingston and others (see p. 221 above) that the maximum of relative transpiration occurs some hours previous to the time of the maximum of the evaporating power of the air. In Fig. I above it will be observed that the relative transpiration maximum fell between I 2 noon and I 2.30 p.m., whilst the evaporating power of the air was greatest between 2 and 3 p.m. 


\section{Knight.-The Interrelations of Stomatal Aperture,}

In the other experiment given, however, the positions were reversed and the relative transpiration maximum fell some $2 \frac{1}{2}$ hours later than that of evaporation.

A review of the series shows that of twenty-six experiments ten were similar to No. I above in showing the 'early maximum' of relative transpiration, whilst of the remainder, six showed the transpiration maximum definitely later than that of evaporation, four showed the two maxima occurring at about the same time, and in six both graphs were falling throughout the experiment. ${ }^{1}$

\section{TABLE II.}

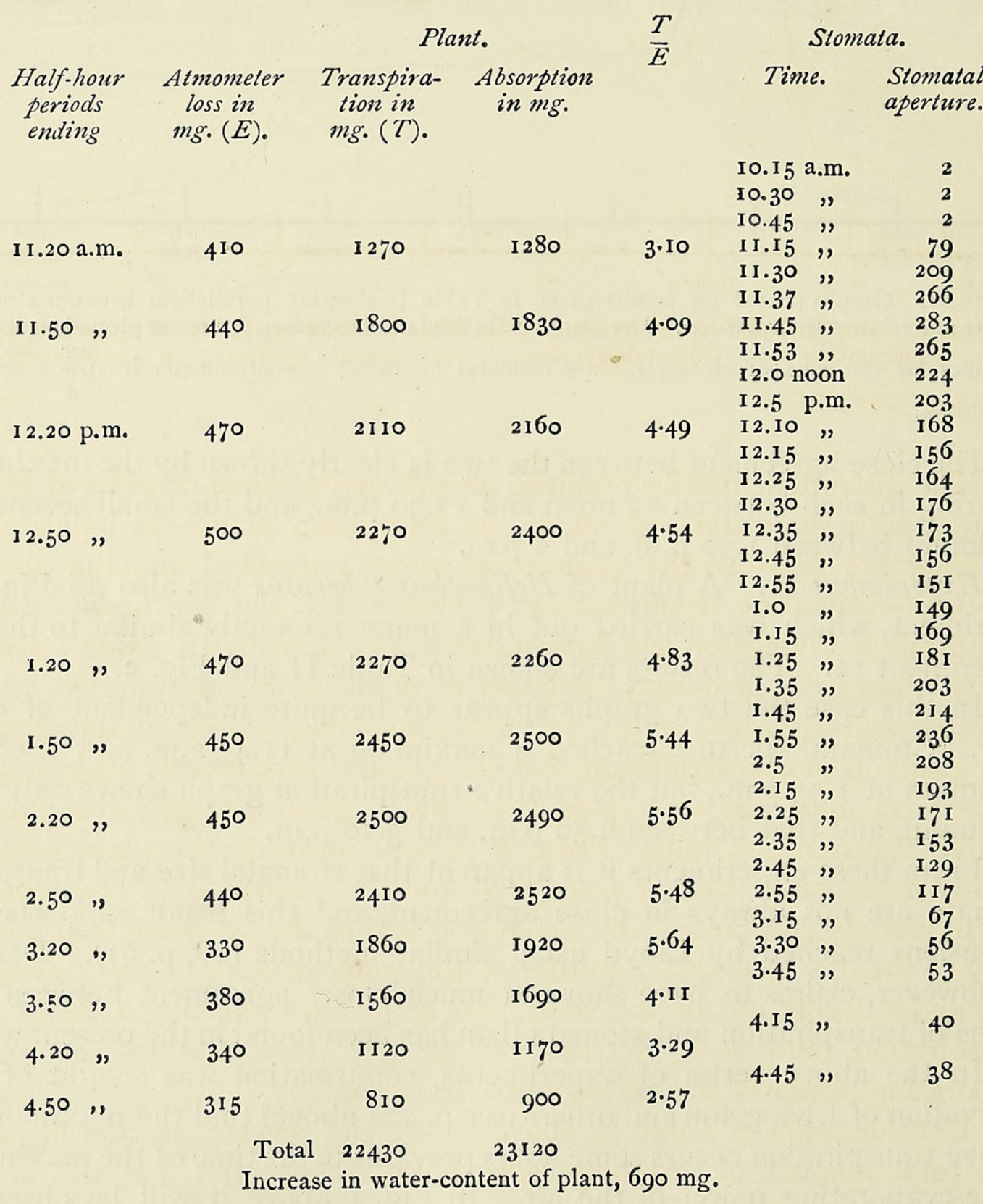

1 It may be noted here that Fig. I above shows the double transpiration maximum observed by some writers, but in the present work this has not appeared with sufficient frequency to warrant any conclusion as to its nature. 


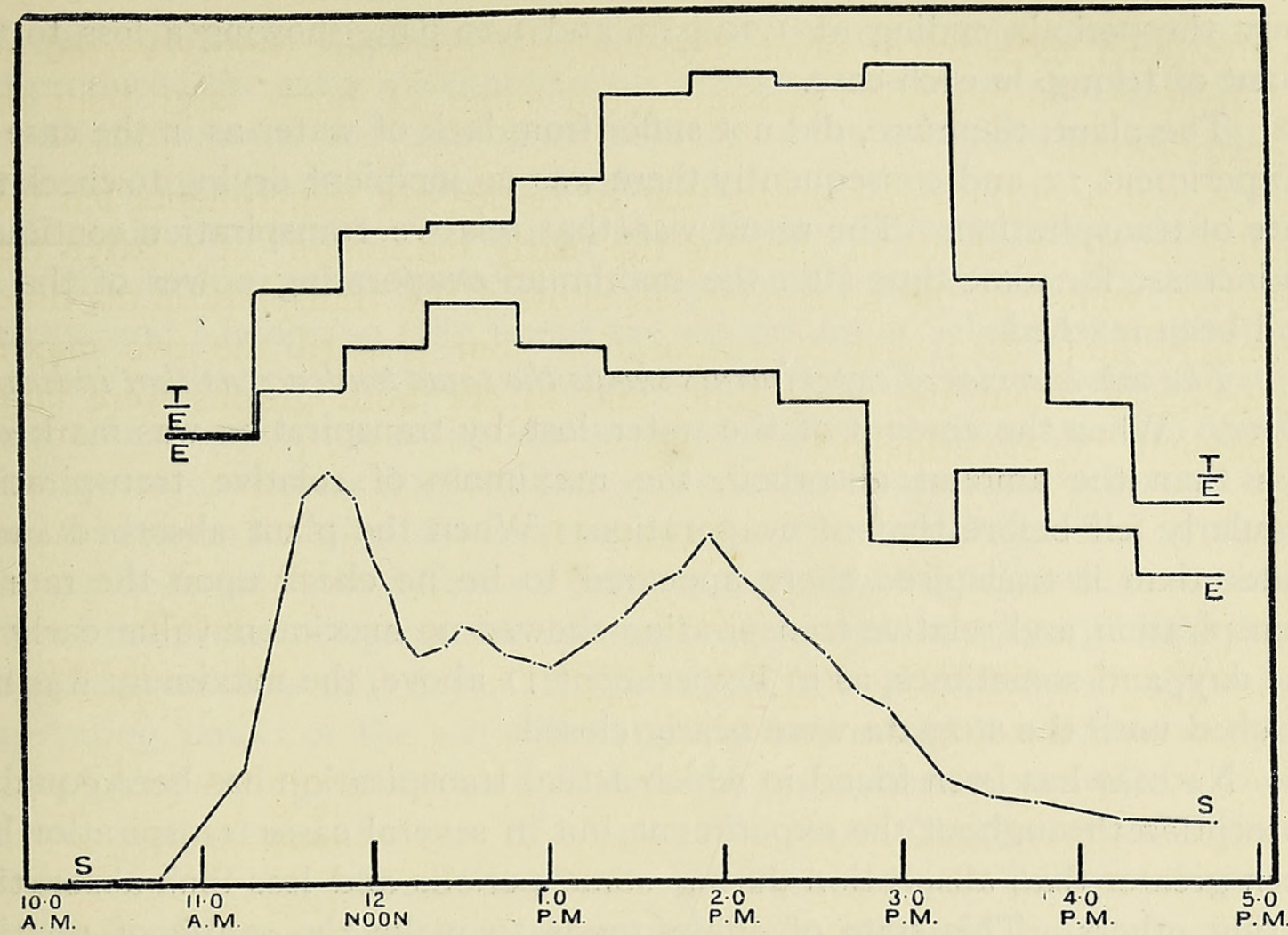

FIG. 2. Graphs (based on the results given in Table II) showing the lack of agreement between relative transpiration and stomatal aperture. $\mathrm{S}=$ stomatal aperture; $\mathrm{E}=$ atmometer loss; $\frac{\mathbf{T}}{\mathbf{E}}=$ relative transpiration.

The discordant results obtained in this series when considered in conjunction with the water-content of the transpiring plant-as indicated by the difference between the quantity of water transpired and the quantity absorbed-constitute confirmatory evidence of the 'incipient drying' hypothesis of Livingston and Brown (see p. 222 above). In Table I above it will be observed that during the experiment the plant transpired i I. $87 \mathrm{grm}$. of water and absorbed only $10.57 \mathrm{grm}$., involving a loss to the plant of $\mathrm{I} \cdot 3 \circ \mathrm{grm}$. It is also significant that the greatest loss, namely $0.45 \mathrm{grm}$., was between 12 noon and 12.30 p.m., from which point onwards the graph of relative transpiration falls. From 3.30 p.m. onwards the plant absorbed slightly more water than it transpired and the transpiration rate remained approximately constant. The conclusion is that the excessive transpiration early in the day caused a lowering of the water-content of the transpiring cells and a drying out of the walls, this in its turn exerting a check upon transpiration (and so a decrease in relative transpiration), before the evaporating power of the air began to decrease.

Consideration of Table II above shows the reverse process in action. The total amount of water transpired was $22.43 \mathrm{grm}$. and the amount absorbed 23.12 grm., a gain of $0.69 \mathrm{grm}$. Throughout the experiment the rate of absorption never fell appreciably below the rate of transpiration, 
only the periods ending at I.20 p.m. and 2.20 p.m. showing a loss to the plant of $10 \mathrm{mg}$. in each case.

The plant, therefore, did not suffer from lack of water as in the case of Experiment I2, and consequently there was no incipient drying to check the rate of transpiration. The result was that relative transpiration continued to increase for some time after the maximum evaporating power of the air had been reached.

The whole series of experiments shows the same tendency as that indicated above. When the amount of the water lost by transpiration was markedly less than the amount absorbed, the maximum of relative transpiration regularly fell before that of evaporation. When the plant absorbed more water than it transpired there appeared to be no check upon the rate of transpiration, and relative transpiration showed no maximum value early in the day, and sometimes, as in Experiment II above, the maximum was not reached until the stomata were nearly closed.

No case has been found in which actual transpiration has been equal to absorption throughout the experiment, but in several cases transpiration has been greater than absorption during some periods and less than absorption during others. This state of affairs tends to make the graph of relative transpiration rather irregular with no definite single maximum. In these experiments it is not possible to correlate each change of water-content of the plant with changes in relative transpiration. It is possible that this is due in part to the inevitable defects of the method of dividing the experiment into half-hour periods for transpiration determinations, coupled with the possibility of a lag in the influence of the quantity of water absorbed by the stem at one end of the shoot on the rate of transpiration from the leaves some distance away.

It should be noted here that in Experiment 12 quoted above, the actual transpiration rate reached a maximum simultaneously with the relative transpiration rate, although this does not occur regularly when the relative transpiration maximum falls before that of evaporation. The theory of incipient drying is not sufficient by itself to account for the fall of the actual transpiration rate, although it explains the decrease of relative transpiration. If transpiration, absorption, and the water-content of the leaf are related in the manner which Livingston's theory suggests, then, other factors being constant, incipient drying will tend to check an increasing transpiration rate (and, conversely, an increase in the water-content of the leaf will tend to check a decreasing transpiration rate) and to bring it to a constant value in equilibrium with the rate of absorption. But transpiration will show no alternation of maxima and minima without the intervention of some factor other than incipient drying, e.g. stomatal closure or decrease in the evaporating power of the air. Shreve appears to have overlooked this relationship in the explanation offered of the two maxima of transpiration (21, pp. 48 
and 49). Shreve's suggestion-that incipient drying checked transpiration, and produced the early maximum, thus allowing the water-supply to catch up with the demand and causing an increase in the transpiration rate up to the second maximum - is clearly inadequate.

There is considerable discrepancy between the results described above and those obtained by other workers. Livingston (17) and Shreve (21), and also Trelease and Livingston (22), found the maximum of relative transpiration to occur regularly before that of evaporation. Also Trelease and Livingston report this transpiration maximum as occurring before the maximum of stomatal aperture, whereas from the present work there appears to be no constant relation between the time of occurrence of these three maxima. The explanation may be found in the difference between the prevailing climatic conditions, some of the present experiments having been carried out on very bright days and others on very dull days. Bright days, with a correspondingly high evaporating power of the air, will naturally favour high transpiration rates and incipient drying, whilst on dull days the transpiration rate will be lower and may not exceed the rate of absorption. Both Livingston and Shreve carried out their experiments at the Desert Laboratory at Tucson, where the relative humidity of the atmosphere was very low and the temperature fairly high-conditions favouring the early onset of incipient drying and so producing the early maximum of relative transpiration.

\section{Stomata and Leaf Water-Content.}

Lloyd (20) found that frequently the stomata continued to open when the water-content of the plant was decreasing, and concluded from this that the stomata were 'ineffectual in maintaining a constant supply of leafwater'. The results of Trelease and Livingston mentioned above, showing that the stomata continue to open for some three hours after the transpiration maximum is reached, confirm Lloyd's experiments, since the watercontent of the leaf must decrease with the onset of incipient drying which occurs before the maximum of relative transpiration is reached. In other words, the stomata continue to open whilst the water-content of the leaf is decreasing.

The same result has been found in the present experiments. When the water-content of the plant is decreasing owing to the excess of transpiration over absorption, the stomata often continue to open, thus tending to increase the rate of transpiration.

Experiment 12 quoted above provides an example of this. Transpiration exceeded absorption (and therefore the water-content of the plant decreased) from the commencement of the experiment at II.O a.m. until $3.30 \mathrm{p} . \mathrm{m}$., but the stomata continued to open until I2.I5 p.m. A further example is given below. 
Experiment so. The day was bright and hot, the maximum temperature being $9 \mathrm{I} \cdot 5^{\circ} \mathrm{F}$. A shoot of Helianthus tuberosus was set up in the usual way and records of transpiration, absorption, evaporation, stomatal aperture, temperature, and humidity were kept. The results are shown in Table III and Fig. 3 .

\section{TABLE III.}

The numbers in the 'Water deficit' column represent the excess of total transpiration over total absorption at the end of each period.

\begin{tabular}{|c|c|c|c|c|c|c|c|c|}
\hline \multirow[b]{2}{*}{$\begin{array}{l}\text { Half-hour } \\
\text { periods } \\
\text { ending }\end{array}$} & \multirow[b]{2}{*}{$\begin{array}{l}\text { Atmometer } \\
\text { loss in } \\
m g .(E) .\end{array}$} & \multicolumn{2}{|c|}{ Plant. } & \multirow[b]{2}{*}{$\begin{array}{c}\text { Water } \\
\text { deficit in } \\
\text { mg. }\end{array}$} & \multirow{2}{*}{$\frac{T}{E}$} & \multicolumn{3}{|c|}{ Stomata. } \\
\hline & & $\begin{array}{l}\text { Transpira- } \\
\text { tion in } \\
\text { mg. }(T) .\end{array}$ & $\begin{array}{l}\text { Absorption } \\
\text { in mg. }\end{array}$ & & & Time & & $\begin{array}{l}\text { Stomatal } \\
\text { aperture. }\end{array}$ \\
\hline & & & & & & $\begin{array}{l}9.55 \text { a } \\
\text { I0.3 } \\
\text { I0.10 }\end{array}$ & $\begin{array}{l}\text { a.m. } \\
",\end{array}$ & $\begin{array}{l}171 \\
239 \\
265\end{array}$ \\
\hline I0.30 a.m. & 470 & 5870 & 5760 & IIO & I 2.49 & $\begin{array}{l}10.25 \\
10.40 \\
10.55\end{array}$ & $"$ & $\begin{array}{l}299 \\
347 \\
426\end{array}$ \\
\hline $11.0 \quad$, & 580 & 7100 & $673^{\circ}$ & 480 & $\mathrm{I} 2 \cdot 24$ & $\begin{array}{l}\text { II.IO } \\
\text { II. } 25\end{array}$ & $"$ & $\begin{array}{l}568 \\
620\end{array}$ \\
\hline 11.30, & $65^{\circ}$ & 7200 & 6570 & 1110 & II $\cdot 08$ & $\begin{array}{l}\text { I1. } 40 \\
\text { II. } 55\end{array}$ & ", & $\begin{array}{l}620 \\
408\end{array}$ \\
\hline I 2.0 noon & 655 & 5780 & 5330 & I 560 & 8.82 & I2.I5 $\mathrm{P}$ & p.m. & 202 \\
\hline \multicolumn{9}{|c|}{ Potometer refilled at $\mathbf{2} 2$ noon } \\
\hline I 2.35 p.m. & 690 & 4810 & $4420(?)$ & I950 & $6 \cdot 97$ & I 2.30 & " & I 86 \\
\hline & 640 & $375^{\circ}$ & 3760 & I940 & $5 \cdot 86$ & $\begin{array}{l}12.45 \\
\text { I.O } \\
\text { I.I } 5\end{array}$ & ", & $\begin{array}{l}172 \\
\text { I } 54 \\
\text { I3 }\end{array}$ \\
\hline I.35 , & 600 & 3270 & 3330 & 1880 & $5 \cdot 45$ & $\begin{array}{l}\text { I. } 3 \text { O } \\
\text { I. } 45\end{array}$ & ", & $\begin{array}{l}\text { I } 2 \text { I } \\
\text { I I } 3\end{array}$ \\
\hline $2.5 \quad$ & 545 & 2860 & 3090 & $165^{\circ}$ & $5 \cdot 23$ & 2.0 & " & I I 4 \\
\hline
\end{tabular}

The stomata in this case did not begin to close till II.40 a.m., by which time the water-content of the plant had decreased by I.I I grm. owing to the excess of transpiration over absorption. Later in the day, from I2.35 p.m. onwards, the rate of absorption was greater than the rate of transpiration, and the water-content of the plant increased; but in spite of this the stomata continued to close.

It appears from this result that a small decrease in the water-content of the leaf does not produce stomatal closure. The continued opening of the stomata may have been due to increasing illumination, or on the other hand the loss of water may actually have caused the stomata to open as in the case of the preliminary stomatal opening during wilting which was described by Darwin and Pertz (11) and by Laidlaw and Knight (16). Iljin (13) also found open stomata in wilted plants.

Thus the evidence supports Lloyd's contention that stomata do not closely regulate the water-content of the leaf, since there is no stomatal closure in response to incipient drying and consequently no stomatal inhibition of transpiration. 


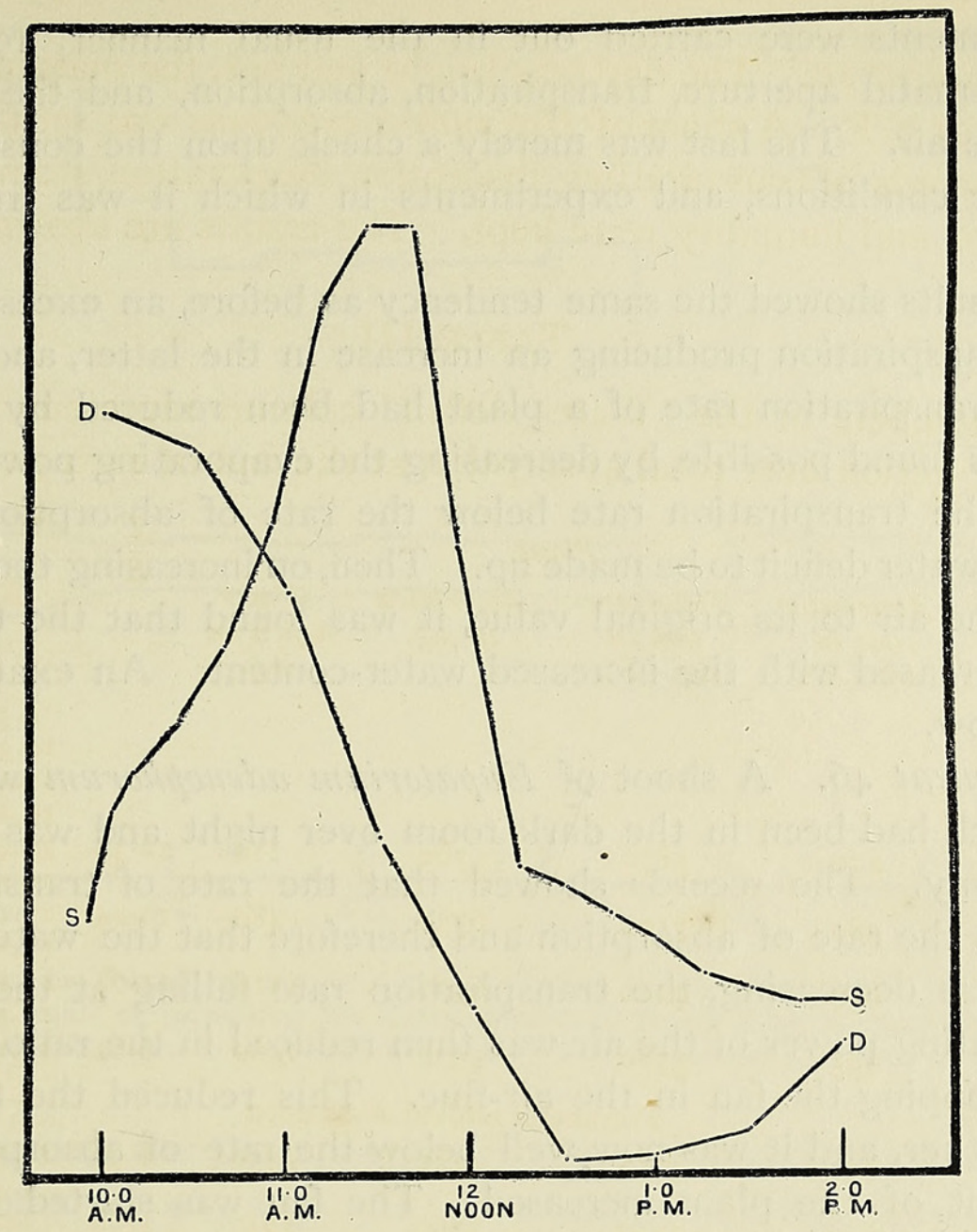

Fig. 3. Graphs (based on the results given in Table III) showing the continued opening of the stomata in spite of the increasing water deficiency. The water deficit numbers are plotted below the zero line so that a downward trend in the graph represents a decreasing water-content, and vice versa. The deficit is assumed to be zero at the beginning of the experiment. $\mathrm{S}=$ stomatal aperture ; $\mathbf{D}=$ water deficit.

\section{EXPERIMENTS IN CONTROLLED ENVIRONMENT.}

It appeared likely from the results obtained that, if stomatal changes and the evaporating power of the air were controlled, the rate of actual transpiration might be shown to be dependent upon the water-content of the plant, and an attempt was made to do this.

The experiments were carried out in a dark room where the temperature could be maintained constant to within $0.5^{\circ} \mathrm{C}$. and the relative humidity to within I per cent. Trials were made with artificial light in order to control the stomata, but it was found that even in the dark the stomata of the plant used-Eupatorium adenophorum-were fairly widely open and that the transpiration rate was still fairly high. Accordingly experiments were carried out in the dark, except when weighings were being made,'when an electric lamp some distance from the plants was switched on. It was found to have no effect on the stomata. The plants were usually removed to the dark room on the day before the experiment was to be performed in order to ensure that they might reach equilibrium in the changed conditions. 
Experiments were carried out in the usual manner, records being made of stomatal aperture, transpiration, absorption, and the evaporating power of the air. The last was merely a check upon the constancy of the atmospheric conditions, and experiments in which it was irregular were discarded.

The results showed the same tendency as before, an excess of absorption over transpiration producing an increase in the latter, and vice versa. When the transpiration rate of a plant had been reduced by the lack of water it was found possible, by decreasing the evaporating power of the air, to reduce the transpiration rate below the rate of absorption and allow some of the water deficit to be made up. Then, on increasing the evaporating power of the air to its original value, it was found that the transpiration rate had increased with the increased water-content. An example of this is given below.

Experiment 46. A shoot of Eupatorium adenophorum was cut from a plant which had been in the dark room over night and was mounted in the usual way. The records showed that the rate of transpiration was greater than the rate of absorption and therefore that the water-content of the plant was decreasing, the transpiration rate falling at the same time. The evaporating power of the air was then reduced in the ratio of about $I \cdot 6$ to $\mathrm{I} \cdot \mathrm{O}$ by stopping the fan in the air-flue. This reduced the transpiration rate still further, and it was now well below the rate of absorption and the water-content of the plant increased. The fan was started again at its original speed after a half-hour period of 'still air', to determine the rate of transpiration with increased water-content. The results are given in Table IV and Fig. 4.

\section{TABLE IV.}

No air movement during period $3 \cdot 30-4.0$ p.m.

Plant. Stomata.

\begin{tabular}{|c|c|c|c|c|c|c|c|}
\hline \multicolumn{2}{|c|}{$\begin{array}{l}\text { Half-hour } \\
\text { periods } \\
\text { ending }\end{array}$} & $\begin{array}{l}\text { Atmometer } \\
\text { water loss } \\
\text { in } m g .(E) \text {. }\end{array}$ & $\begin{array}{c}\text { Transpira- } \\
\text { tion in } \\
m g .(T) .\end{array}$ & $\begin{array}{l}\text { Absorption } \\
\text { in } m g .\end{array}$ & \multicolumn{2}{|c|}{ Time. } & $\begin{array}{l}\text { Stomata } \\
\text { aperture. }\end{array}$ \\
\hline & & & & & II.45 & $\mathrm{m}$ & I 60 \\
\hline $\begin{array}{c}2.30 \\
\text { I.0 }\end{array}$ & o.m. & $\begin{array}{l}222 \\
218\end{array}$ & $5^{18}$ & $\begin{array}{l}33^{\circ} \\
300\end{array}$ & I2.15 & p.m. & I 73 \\
\hline 1.30 & " & 220 & $\begin{array}{l}440 \\
395\end{array}$ & 330 & $\begin{array}{r}\text { I. } \\
\text { I.I }\end{array}$ & " & 186 \\
\hline 2.0 & " & 218 & 405 & 4IO & I. 45 & " & 182 \\
\hline 2.30 & ", & 222 & 400 & $3^{80}$ & 2.15 & " & 189 \\
\hline 3.0 & ", & 220 & 402 & 400 & 2.45 & $"$ & I 88 \\
\hline $3 \cdot 30$ & ", & 220 & $4^{16}$ & $3^{80}$ & 3.15 & $"$ & 183 \\
\hline 4.0 & $"$ & I 35 & 337 & 420 & 3.45 & $"$ & I 88 \\
\hline $4.3^{\circ}$ & " & 225 & $4^{6} 5$ & 390 & 4.15 & " & 190 \\
\hline 5.0 & " & 225 & 447 & $4^{20}$ & $4 \cdot 45$ & " & 192 \\
\hline $5 \cdot 30$ & ", & 222 & $43^{8}$ & 400 & $5 \cdot 15$ & $"$ & 196 \\
\hline & & 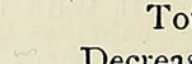 & 4663 & 4250 & - & & \\
\hline
\end{tabular}




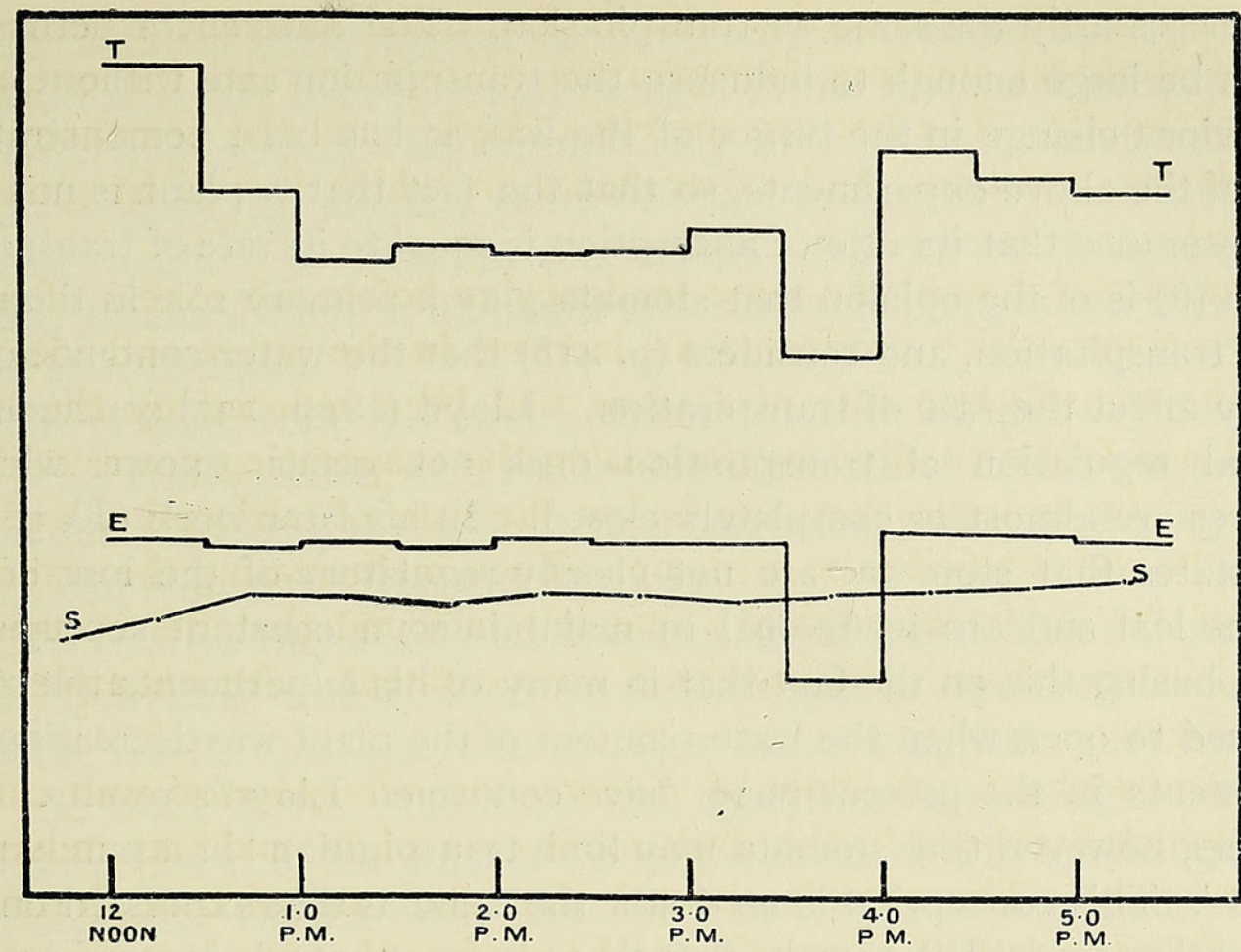

FIG. 4. Graphs (based on results given in Table IV) showing an increase in the transpiration rate as a result of increasing the water-content of the plant by temporarily decreasing the evaporating power of the air. $\mathrm{S}=$ stomatal aperture; $\mathbf{E}=\operatorname{atmometer} \operatorname{loss} ; \mathrm{T}=$ transpiration.

On restarting the fan, transpiration had increased from $400-416 \mathrm{mg}$. per 30 minutes to $465 \mathrm{mg}$. per 30 minutes. Owing, however, to the transpiration rate being again greater than that of absorption, the transpiration rate showed a decrease in the subsequent periods.

The stomatal aperture was not quite constant throughout this experiment, but showed a slight tendency to increase as the experiment proceeded. This may have been due to the effect on the stomata of loss of water (see p. 234 above).

\section{CONCLUSION.}

It appears therefore from the results of these experiments that in plants under quite ordinary conditions, changes of stomatal aperture and transpiration do not necessarily run parallel. Darwin (9) claims a much closer correlation between these two functions than has been obtained in the present work, but Darwin made no attempt to control his experimental conditions, ${ }^{1}$ and most of his transpiration measurements were based upon readings of absorption by the plant from a potometer, uncontrolled by weighing; although, as has been frequently shown, absorption is not by any

1 It should be noted that Darwin's results were very divergent, as his Tables VII and VIII, pp. 433 and 434, show. He compared the increase of transpiration and the increase in stomatal aperture in response to light, and this ratio, which in accordance with his theory should be unity, varies from $5 \cdot 5$ to less than $0 \cdot 2$. 
means necessarily the same as transpiration. The differences between the two can be large enough to influence the transpiration rate without causing any obvious change in the turgor of the leaf, as has been demonstrated by many of the above experiments, so that the fact that a plant is not flaccid is no assurance that its rate of absorption is equal to its rate of transpiration. Darwin (9) is of the opinion that stomata play a primary rôle in the regulation of transpiration, and considers (p. $4 \mathrm{\tau} 8$ ) that the water-content does not sensibly affect the rate of transpiration. Lloyd (19, p. I37) concluded that stomatal regulation of transpiration does not occur, except when the apertures are almost or completely closed. In his later work (20, p. I4) he again states that stomata 'are not closely regulatory of the loss of water from the leaf and are ineffectual in maintaining a constant supply of leaf water', basing this on the fact that in many of his experiments the stomata continued to open when the water-content of the plant was decreasing. The experiments in the present paper have confirmed Lloyd's results. Lloyd considers, however, that stomata may limit transpiration 'in a purely passive manner'. This conception is no doubt the same as that expressed on p. $13^{8}$ of his earlier work (19), namely, that there is no stomatal closure in anticipation of wilting, to conserve the water-supply. It is clear, however, that if the difference between the partial pressures of water vapour on the two sides of the epidermis is constant, a decrease in the size of the stomatal apertures is bound to decrease the rate at which moisture diffuses through to the outer air, so that a change in the size of the stomatal apertures must result in a change in the transpiration rate. Limitation of transpiration by stomata in this manner is presumably what Lloyd conceives as the 'passive' regulation. It is unlikely that any one would maintain that stomata are capable of adaptive closure in anticipation of wilting, if by 'wilting' is meant a decrease in the water-content of the leaf. By 'closure in anticipation of wilting', Lloyd doubtless means closure in response to a reduction of water-content, thereby preventing the further loss which would otherwise occur. The response of stomata to loss of water from the leaf has been indicated by the experiments of Darwin and Pertz (11), of Lloyd (20), and of Laidlaw and Knight (16), and also in the present work. A small decrease in the watercontent of the leaf does not cause the stomata to close, and as the loss of water proceeds the first noticeable effect of wilting is to cause the stomata to open. ${ }^{1}$ Closure finally takes place only at a comparatively late stage of wilting.

Iljin (13) concluded that an excessive transpiration rate caused stomatal closure, but his statements that open stomata are often found in wilted plants, and that the rate of stomatal closure is not dependent upon the rate at which the water-content of the plant is reduced, confirm the work mentioned above.

1 Lloyd failed to find any evidence of preliminary stomatal opening due to wilting. 
Stomatal changes appear to be chiefly influenced by conditions of illumination rather than by small changes in the leaf water-content. Since the water-content may vary within fairly wide limits without causing any stomatal change, the stomata cannot be said to function in maintaining the requisite quantity of water in the leaf by response to changes of watercontent, although there is no doubt that stomatal changes can influence the rate of transpiration.

The present work has shown the importance of leaf water-content in influencing transpiration, thus confirming the work of Livingston and Brown (18) in demonstrating that a small decrease in leaf water, producing incipient drying, can reduce the transpiration rate.

The relative importance of incipient drying and stomatal size as the factor controlling transpiration probably depends upon other conditions. From the results obtained in these experiments it appears that in a bright light the stomata are wide open, and that therefore changes in intrinsic transpiring power of the plant are brought about chiefly by changes of leaf water-content. On the other hand, in a dull light it is probable that the lower transpiration rate is the result of the failure of the stomata to open widely, and incipient drying will not occur so long as the supply of water through the stem is maintained.

The direct effect of light on the transpiration of a plant, i.e. the effect of light on the rate of water loss from the evaporating tissues, has not yet been investigated in the present work. Darwin (10) by a new method experimented on this factor and concluded that the direct effect of light might be considerable, the transpiration rate, irrespective of the influence of stomatal change, being as much as $3^{6}$ per cent. greater in light than in darkness, but the nature of this direct effect is as yet obscure.

\section{SUMMARY.}

Experiments have been carried out with various plants under controlled atmospheric conditions to determine the relationship between stomatal aperture and the rate of transpiration.

I. The results have shown that in many cases there is no agreement between the two, a decreasing transpiration rate being often accompanied by stomatal opening, and vice versa.

2. The water-content of the leaf was found to be a factor playing a large part in the control of transpiration, a high water-content tending to produce a high transpiration rate, and a lower transpiration rate resulting from decreased water-content.

3. The stomatal aperture is not reduced by slight water deficiency in the leaf; hence the ordinary view that stomata, by their response to incipient drying, are the chief factors in maintaining the water-content of the leaf is not tenable. 
4. On the other hand, the stomata are very sensitive to light changes, so that with increasing light intensity the stomata may continue to open whilst the water-content of the leaf is decreasing.

\section{LITERATURE CITED.}

1. BAKke, A. L.: Studies on the Transpiring Power of Plants as indicated by the Method of Standardized Hygrometric Paper. Journal of Ecology, vol. ii, I914, p. I45.

2. BAKKe, A. L., and Livingston, B. E. : Further Studies on Foliar Transpiring Power of Plants. Physiological Researches, No. I2, 1916.

3. Balls, W. L.: The Stomatograph. Proc. Roy. Soc., B., vol. lxxxv, 1912, p. 40.

4. Blackman, V. H., and Knight, R. C. : A Method of Controlling Air Movement in Transpiration Experiments. Ann. of Bot., vol. xxxi, I9I 7, p. 2 I 7 .

5. BRiggs, L. J., and Shantz, H. L. : Hourly Transpiration Rate on Clear Days as Determined by Cyclic Environmental Factors. Journ. Agr. Research, vol. v, 1916, p. 583 .

6. Curtis, C. C. : Some Observations on Transpiration. Bull. Torrey Bot. Club, vol. xxix, I902, p. 360.

7. Darwin, F.: Observations on Stomata. Phil. Trans. Roy. Soc., B., vol. cxc, I898, p. 53I.

8. - A Self-recording Method applied to Movements of Stomata. Bot. Gazette, xxxvii, 1904, p. 8r.

9. - On the Relation between Transpiration and Stomatal Aperture. Phil. Trans. Roy. Soc., B., vol. ccvii, 1916, p. $4^{1} 3$.

10. - The Effect of Light on the Transpiration of Leaves. Proc. Roy. Soc., B., vol. 1xxxvii, I9I 4, p. 28I.

11. Darwin, F., and Pertz, D. F. M. : New Method of estimating Aperture of Stomata. Proc. Roy. Soc., B., vol. lxxxiv, I9I I, p. I36.

12. Giddings, L. A.: The Transpiration of Silphium laciniatum. Plant World, vol. xvii, I9I4, p. 309 .

13. ILjIN, W. S.: Die Regulierung der Spaltöffnungen mit der Veränderung des osmotischen Druckes. Beih. z. Bot. Centralbl., vol. xxxii, 1914, p. I5.

14. Knight, R. C.: A Convenient Modification of the Porometer. New Phytologist, vol. xiv, I9I 5 , p. 2 I 2 .

15. $:$ On the Use of the Porometer in Stomatal Investigation. Annals of Botany, vol. $\mathrm{xxx}, 1916, \mathrm{p} .5 \%$.

16. Laidlaw, C. G. P., and Knight, R. C. : A Description of a Recording Porometer and a Note on Stomatal Behaviour during Wilting. Annals of Botany, vol. xxx, 1916, p. 47.

17. Livingston, B. E.: The Relation of Desert Plants to Soil Moisture and to Evaporation. Carnegie Inst. Pubn., No. 1, I906.

18. Livingston, B. E., and Brown, W. H.: The Relation of the March of Transpiration to Variations of Water Content of Foliage Leaves. Botanical Gazette, vol. liii, 1912, p. 309 .

19. Lloyd, F. E. : The Physiology of Stomata. Carnegie Inst. Pubn., No. lxxxix, 1908.

20. : The Relation of Transpiration and Stomatal Movements to Water Content of Leaves of Fouquieria splendens. Plant World, vol. xv, I9I 2, p. I.

21. Shreve, E. B.: The Daily March of Transpiration in a Desert Perennial. Carnegie Inst. Pubn., No. cxciv, I9I4.

22. Trelense, S. F., and Livingston, B. E. : The Daily March of Transpiring Power as indicated by the Porometer and by Standardized Hygrometric Paper. Journal of Ecology, vol. iv, I9I6, p. I. 


\section{$2 \mathrm{BHL}$ Biodiversity Heritage Library}

Knight, R. C. 1917. "The interrelations of stomatal aperture, leaf

water-content, and transpiration rate." Annals of botany 31, 221-240.

https://doi.org/10.1093/oxfordjournals.aob.a089642.

View This Item Online: https://www.biodiversitylibrary.org/item/232813

DOI: https://doi.org/10.1093/oxfordjournals.aob.a089642

Permalink: https://www.biodiversitylibrary.org/partpdf/320185

\section{Holding Institution}

Smithsonian Libraries

\section{Sponsored by}

Biodiversity Heritage Library

\section{Copyright \& Reuse}

Copyright Status: Not in copyright. The BHL knows of no copyright restrictions on this item.

This document was created from content at the Biodiversity Heritage Library, the world's largest open access digital library for biodiversity literature and archives. Visit BHL at https://www.biodiversitylibrary.org. 